Correspondence Elena P. Ivanova eivanova@swin.edu.au

\section{Pseudomonas brassicacearum subsp. neoaurantiaca subsp. nov., orange-pigmented bacteria isolated from soil and the rhizosphere of agricultural plants}

\author{
Elena P. Ivanova, ${ }^{1,2}$ Richard Christen, ${ }^{3}$ Chantal Bizet, ${ }^{4}$
} Dominique Clermont, ${ }^{4}$ Laurence Motreff, ${ }^{5}$ Christiane Bouchier, ${ }^{5}$ Natalia V. Zhukova, ${ }^{6}$ Russell J. Crawford ${ }^{1}$ and Elena A. Kiprianova ${ }^{7}$

\footnotetext{
${ }^{1}$ Swinburne University of Technology, Faculty of Life and Social Sciences, PO Box 218, Hawthorn, Victoria 3122, Australia

${ }^{2}$ Pacific Institute of Bioorganic Chemistry of the Far-Eastern Branch of the Russian Academy of Sciences, 690022 Vladivostok, Pr. 100 Let Vladivostoku 159, Russian Federation

${ }^{3}$ Université de Nice Sophia Antipolis and CNRS UMR 6543, Centre de Biochimie, Laboratoire de Biologie Virtuelle, Campus Valrose, F-06108 Nice, France

${ }^{4}$ Collection de l'InstitutPasteur, InstitutPasteur, 28 rue du Docteur Roux, F-75724 Paris Cedex 15, France

${ }^{5}$ Plate-forme Génomique, Institut Pasteur, 28 rue du Docteur Roux, F-75724 Paris Cedex 15, France

${ }^{6}$ Institute of Marine Biology of the Far-Eastern Branch of the Russian Academy of Sciences, 90041 Vladivostok, Russian Federation

${ }^{7}$ D. K. Zabolotny Institute of Microbiology and Virology, Ukrainian Academy of Sciences, 03680 Kiev, Ukraine
}

\begin{abstract}
A large group of 38 strains of saprophytic bacteria was isolated from soil and the rhizosphere of agricultural plants. The novel organisms were Gram-negative, aerobic, rod-shaped bacteria that produced a green fluorescent pigment, a red-orange diffusible pigment and a complex mixture of phloroglucinol derivates with antimicrobial activity. The latter have not been found in other bacteria, but are peculiar to ferns. The bacteria were vigorous denitrifiers that synthesized levan from sucrose and liquefied gelatin, but were found not to degrade aesculin, starch, agar, Tween 80 or DNA. Bacterial growth was found to occur at $4{ }^{\circ} \mathrm{C}$ but not at $40{ }^{\circ} \mathrm{C}$. The predominant cellular fatty acids were $16: 0$, $16: 1(n-7), 18: 1(n-7)$ and $17: 0$ cyclo. The $G+C$ content of the novel bacteria was $61.0-62.9$ mol\%. $16 \mathrm{~S}$ rRNA gene sequence analysis indicated that the representative strain CIP $109457^{\top}$ had a clear affiliation with Pseudomonas sensu stricto groups, with the nearest relatives being Pseudomonas brassicacearum, $P$. thivervalensis, $P$. corrugata, $P$. mediterranea and $P$. kilonensis. DNA-DNA hybridization experiments showed that the group of isolated strains exhibited high levels of genetic relatedness (81-100\%), confirming that they are representatives of the same species. At the same time, they bound at low levels (4-46\%) with DNA of the type strains of their nearest relatives with the exception of $P$. brassicacearum; DNA binding of $90 \%$ with the DNA of $P$. brassicacearum CIP $107059^{\top}$ suggested that the bacteria studied belong to this species. Analysis of taxonomic data indicated that the group of novel bacteria maintain a distinct phenotypic profile, allowing the description of novel subspecies within P. brassicacearum, for which the following names are proposed: Pseudomonas brassicacearum subsp. brassicacearum subsp. nov. (type strain DBK $11^{\top}=\mathrm{CFBP} 11706^{\top}=\mathrm{CIP}$ $\left.107059^{\top}=\mathrm{DSM} 13227^{\top}=\mathrm{JCM} 11938^{\top}\right)$ and $P$ seudomonas brassicacearum subsp. neoaurantiaca subsp. nov., with the type strain CIP $109457^{\top}\left(=\right.$ ATCC $49054^{\top}=\operatorname{IMV} 387^{\top}=$ VKM B-1524 $\left.4^{\top}\right)$.
\end{abstract}

The GenBank/EMBL/DDBJ accession number for the 16S rRNA gene sequence of strain CIP $109457^{\top}$ is EU391388.

Details of strain isolation and DNA-DNA hybridization results are available as supplementary material with the online version of this paper.
Over the last few decades, the species of the genus Pseudomonas have undergone several reclassifications (Palleroni, 1984, 2005). Currently, the genus Pseudomonas sensu stricto consists of several intrageneric 
clusters, including the Pseudomonas syringae, P. chlororaphis, $P$. fluorescens, $P$. putida, $P$. stutzeri and $P$. aeruginosa groups. Nonetheless, different hierarchical arrangements among the species of Pseudomonas sensu stricto have been reported repeatedly, indicating continuing difficulties associated with the taxonomic affiliation of pseudomonads (Moore et al., 1996; Anzai et al., 2000; Yamamoto et al., 2000; Ait Tayeb et al., 2005).

During a taxonomic investigation of Pseudomonas-like bacteria that produce antibacterial compounds (Kiprianova et al., 1985), we isolated a large group of orange-pigmented bacteria from soil and the rhizosphere of agricultural plants that were found to be phenotypically similar to Pseudomonas aurantiaca. The latter species was originally described by Nakhimovskaya in 1948. Concurrently, it was shown that the DNA of the type strain of this species bound at high levels (82\%) with DNA of the type strain of Pseudomonas aureofaciens (Kiprianova et al., 1985). Recently, the taxonomic status of these species was updated to create three subspecies within $P$. chlororaphis: P. chlororaphis subsp. chlororaphis, P. chlororaphis subsp. aureofaciens and $P$. chlororaphis subsp. aurantiaca (Peix et al., 2007). The taxonomic status of our group of soil bacteria remained unclear. This study was aimed at clarifying the taxonomic affiliation of these bacteria. It was revealed that they differed genetically and phylogenetically from the subspecies of $P$. chlororaphis and other phylogenetic relatives such as Pseudomonas thivervalensis, $P$. corrugata, $P$. mediterranea and $P$. kilonensis, and that they are close to Pseudomonas brassicacearum on a genomospecies level. The characteristic phenotypic profile of the group of orange-pigmented bacteria allows them to be distinguished readily from close relatives including $P$. brassicacearum, thus justifying the proposal of a novel subspecies within P. brassicacearum.

A total of 38 strains of Pseudomonas were isolated from different sources in Kiev and western Ukraine in the period 1971-1989 (Supplementary Table S1, available in IJSEM Online) as described previously (Kiprianova et al., 1985; Smirnov \& Kiprianova, 1990). All strains were maintained on trypticase soy agar (TSA) plates and stored at $-80{ }^{\circ} \mathrm{C}$ in a medium containing $4 \%(\mathrm{w} / \mathrm{v})$ tryptic soy broth (TSB; $\mathrm{pH} 7.2)$ and $20 \%(\mathrm{v} / \mathrm{v})$ glycerol.

Cell morphology was determined after growth for $24 \mathrm{~h}$ on TSA (Oxoid) at $28{ }^{\circ} \mathrm{C}$. The motility of bacteria was determined by examining $18 \mathrm{~h}$ cultures in TSB. The ability of the bacteria to produce pigments was tested on King A and B medium (King et al., 1954). The physiological and biochemical properties of the isolated bacteria were also examined. These included their glucose metabolism (Hugh \& Leifson, 1953), catalase and oxidase activity, ability to denitrify and liquefy gelatin, arginine dihydrolase, lysine decarboxylase and ornithine decarboxylase activities, the ability to secrete extracellular hydrolytic enzymes (proteases, lecithinases, lipases, amylases) and the ability to produce levan from sucrose and to oxidize gluconate to 2 - ketogluconate. Unless indicated otherwise, all physiological and biochemical tests were carried out according to the methods described by Stanier et al. (1966).

The 38 strains isolated from soil and rhizosphere of plants exhibited all of the phenotypic characteristics of Pseudomonas sensu stricto; their characteristics are shown in the species description and Table 1. The bacteria were found to utilize a wide spectrum of organic compounds as sources of carbon and energy to enable growth. API ZYM tests were performed only for the type strain.

Most of the strains (about $90 \%$ ) grown on King A medium were found to produce an extracellular water- and alcoholsoluble red-orange pigment with $\lambda_{\max } 280$ and $510 \mathrm{~nm}$. A complex mixture of antimicrobial phloroglucinol derivates was also synthesized concurrently with pigment production. The main component of this complex was found to be the antibacterial and antifungal agent 2,4-diacetylphloroglucinol. Minor components were identified as triacetylphloroglucinol, phloroacetophenone and biologically active phloroglucide di-(2,4-diacetylphloroglucinol) methane (Kiprianova et al., 1985; Smirnov \& Kiprianova, 1990). Compounds similar to the latter component have not been found in other bacteria, but are peculiar to ferns and are used as anthelmintics. All the compounds listed above were produced by all freshly isolated bacteria. However, the ability of these bacteria to produce antimicrobial compounds reduced significantly during prolonged preservation in the laboratory.

Analysis of fatty acid methyl ethers was performed by GLC as described previously (Svetashev et al., 1995). The fatty acid profiles of five representative strains of the group were obtained. The bacteria were similar to other representatives of the genus Pseudomonas sensu stricto with regard to their fatty acid composition. Fatty acids with an even number of carbon atoms dominated: $16: 0(36.7 \pm 6 \%), 16: 1(\mathrm{n}-7)$ $(32.4 \pm 3 \%)$ and $18: 1(n-7)(16.9 \pm 3 \%)$. Cells also contained 17:0 cyclo $(9.5 \% \pm 2 \%)$. Among the minor components, $14: 0,15: 0,18: 0$ and 19:0 cyclo were found.

For 16S rRNA gene sequencing, genomic DNA was obtained following lysis of bacterial cells by suspension in $200 \mu \mathrm{l}$ water and boiling for $10 \mathrm{~min}$ at $100{ }^{\circ} \mathrm{C}$. After centrifugation, an aliquot $(5 \mu \mathrm{l})$ of the supernatant was used for PCR amplification of the 16S rRNA gene with primers A ( $5^{\prime}$-AGAGTTTGATCATGGCTCAG- $\left.3^{\prime}\right)$ and $\mathrm{H}$ (5'-AAGGAGGTGATCCAACCGCA-3') (Brosius et al., 1978). The PCR conditions were as follows: after an initial denaturation step at $94{ }^{\circ} \mathrm{C}$ for $4 \mathrm{~min}$, the reaction mixture was run through 25 cycles of denaturation at $94{ }^{\circ} \mathrm{C}$ for $1 \mathrm{~min}$, an annealing step at $57^{\circ} \mathrm{C}$ for $1 \mathrm{~min}$ and an extension step at $72{ }^{\circ} \mathrm{C}$ for $2 \mathrm{~min}$. The amplification primers used in this study gave a $1.5 \mathrm{~kb}$ PCR product. PCR products were purified, using polyacrylamide P-100 gel (Bio-Gel P-100; Bio-Rad), by 96-well plate filtration (Millipore). Sequencing reactions were performed using an ABI PRISM BigDye Terminator cycle sequencing ready 
Table 1. Characteristics that differentiate the novel strains from $P$. brassicacearum and some other phylogenetically related species

Taxa: 1, P. brassicacearum subsp. neoaurantiaca subsp. nov.; 2, P. brassicacearum subsp. brassicacearum subsp. nov.; 3, P. thivervalensis; 4 , P. corrugata; 5, P. mediterranea; 6, P. kilonensis. Data from this study and from Achouak et al. (2000), Sikorski et al. (2001) and Catara et al. (2002). Numbers in parentheses represent the number of novel strains that gave a positive reaction. ND, No data available; $v$, variable reaction.

\begin{tabular}{|c|c|c|c|c|c|c|}
\hline Characteristic & 1 & 2 & 3 & 4 & 5 & 6 \\
\hline Colony texture & Smooth & Mucoid & Mucoid & $\begin{array}{l}\text { Wrinkled or } \\
\text { smooth }\end{array}$ & $\begin{array}{l}\text { Wrinkled or } \\
\text { smooth }\end{array}$ & Smooth \\
\hline $\begin{array}{l}\text { Green fluorescent } \\
\text { pigment }\end{array}$ & $+(38)$ & + & + & - & - & + \\
\hline Other pigments & $\begin{array}{l}\text { Orange pigment } \\
\text { (aromatic), } \\
\text { phloroglucinol } \\
\text { derivates }\end{array}$ & $\begin{array}{l}\text { Brown-orange } \\
\text { pigment }\end{array}$ & $\begin{array}{l}\text { Brown-orange } \\
\text { pigment }\end{array}$ & $\begin{array}{l}\text { Yellow to brown } \\
\text { pigment in some } \\
\text { strains }\end{array}$ & $\begin{array}{l}\text { Yellow to brown } \\
\text { pigment in } \\
\text { some strains }\end{array}$ & $\begin{array}{l}\text { Dark-brown } \\
\text { pigment after } \\
2-3 \text { weeks of } \\
\text { incubation }\end{array}$ \\
\hline Levan production & $+(38)$ & + & + & - & - & ND \\
\hline $\begin{array}{l}\text { Reduction of nitrate } \\
\text { to nitrite }\end{array}$ & $+(38)$ & $\mathrm{V}$ & $\mathrm{V}$ & + & + & - \\
\hline Denitrification & $+(38)$ & - & - & - & - & - \\
\hline Arginine dihydrolase & $+(38)$ & + & + & $\mathrm{V}$ & $\mathrm{v}$ & - \\
\hline DNase & $-(0)$ & + & + & - & - & $\mathrm{ND}$ \\
\hline \multicolumn{7}{|l|}{ Assimilation of: } \\
\hline D-Sorbitol & $+(38)$ & + & + & - & - & - \\
\hline D-Mannitol & $+(38)$ & - & - & + & + & + \\
\hline meso-Tartrate & $-(2)$ & - & - & - & + & - \\
\hline L-Histidine & $+(38)$ & - & - & - & - & - \\
\hline Benzoate & $+(36)$ & + & - & - & - & - \\
\hline Ethanol & $+(38)$ & ND & ND & ND & $\mathrm{ND}$ & ND \\
\hline D-Fucose & $-(0)$ & - & - & - & - & + \\
\hline
\end{tabular}

reaction kit and run on a 3700 Genetic Analyzer (Applied Biosystems) with eight sequencing primers.

The 16S rRNA gene sequence of a representative strain, CIP $109457^{\mathrm{T}}$, was compared by BLAST against a database of cultured species only (http://bioinfo.unice.fr/blast) and a database of type strains (EzTaxon; Chun et al., 2007) (http://147.47.212.35:8080) in order to retrieve the 50 most similar sequences, that were then aligned with Clustal2 (Larkin et al., 2007). Alignments were then checked manually with SeaView (Galtier et al., 1996) and domains common to all sequences were used to derive a first phylogenetic tree using SeaView (new version). This tree allowed the new strains to be identified as strains of Pseudomonas. The sequences of all Pseudomonas type strains were then used for further studies. Alignments were checked again and a full phylogenetic analysis was undertaken using the BIONJ and maximum-likelihood algorithms, excluding positions containing indels and unknown nucleotides. For the neighbour-joining analysis, a distance matrix was calculated using Kimura's twoparameter correction. Bootstrap analysis was performed using 1000 replications. BIONJ was carried out according to Gascuel (1997) and maximum-likelihood was determined using PhyML (Guindon \& Gascuel, 2003). Conflicting phylogenies in many parts of the tree and low bootstrap values confirmed the difficulty of resolving a phylogeny within the genus Pseudomonas using 16S rRNA gene sequences (data not shown). Phylogenetic trees were drawn using TreeDyn (Chevenet et al., 2006) and SeaView.

$16 \mathrm{~S}$ rRNA gene sequence analysis revealed that CIP $109457^{\mathrm{T}}$ is a member of the Gammaproteobacteria, since its sequence grouped within the saprophytic, fluorescent pseudomonads (Fig. 1), and indicated clearly that this organism should be included in the genus Pseudomonas. The closest phylogenetic neighbour (99.2-99.5\% $16 \mathrm{~S}$ rRNA gene sequence similarity) of CIP $109457^{\mathrm{T}}$ was the type strain of $P$. brassicacearum; other close relatives may be $P$. thivervalensis, $P$. corrugata, $P$. kilonensis and $P$. mediterranea (but the close relationships were not supported by all methods and bootstrap analysis; Fig. 1).

DNA from type strains of Pseudomonas species initially selected on the basis of their phenotypic similarity was isolated according to the method described by Marmur (1961). DNA from P. brassicacearum CIP $107059^{\mathrm{T}}$ was isolated using a French pressure cell (Thermo Spectronic) and was purified by chromatography on hydroxyapatite as described by Cashion et al. (1977). The G + C content of the DNA of the newly isolated strains ranged from 61.0 to $62.9 \mathrm{~mol} \%$, as determined by the thermal denaturation method of Marmur \& Doty (1962). Since the group of 38 strains exhibited nearly identical phenotypic characteristics, only five representative strains were selected for DNADNA hybridization (listed in Supplementary Table S2). The reference strains obtained for DNA-DNA hybridiza- 


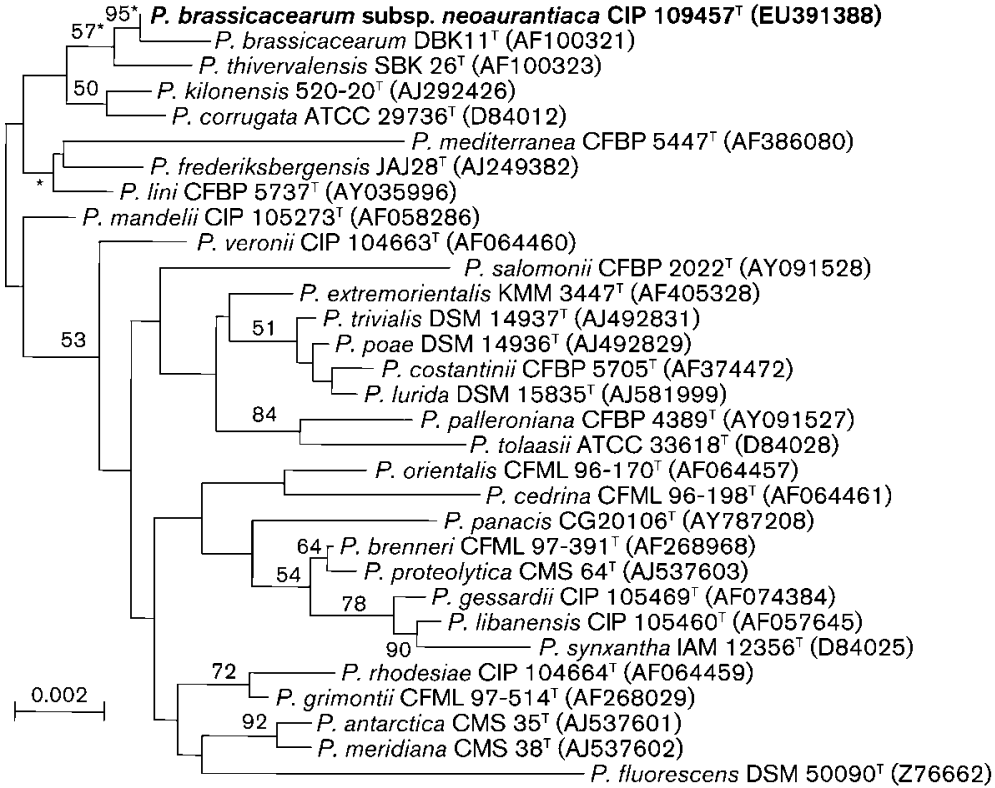

Fig. 1. Phylogenetic position of Pseudomonas brassicacearum subsp. neoaurantiaca CIP $109457^{\top}$ within the genus Pseudomonas based on $16 \mathrm{~S}$ rRNA gene sequences. The topology is that of the BIONJ analysis, with branches also found by maximum-likelihood shown by asterisks; numbers indicate percentages of bootstrap replication $(\geqslant 50 \%)$. Bar, 0.002 substitutions per nucleotide position. tion experiments (Supplementary Table S2) were routinely cultured on TSA plates. DNA-DNA hybridization was performed spectrophotometrically and initial renaturation rates were recorded according to the method described by Marmur \& Doty (1962) and De Ley et al. (1970). The reassociation temperature was $70{ }^{\circ} \mathrm{C}$. The $\Delta T_{\mathrm{m}}$ (difference between the $T_{\mathrm{m}}$ of the homoduplex and the heteroduplex) was $3-4{ }^{\circ} \mathrm{C}$. The DNA-DNA relatedness of the strains representing the group ranged from 81 to $100 \%$, indicating that the strains belong to the same genomospecies. An extended DNA-DNA hybridization study with strain CIP $109457^{\mathrm{T}}$ and the type strains of the $P$. chlororaphis group, some other phenotypically similar species (mentioned above) including $P$. fluorescens and the closest phylogenetic neighbour P. brassicacearum showed that its DNA bound at low levels (4-46\%) with the DNA of all type strains except P. brassicacearum (90\%) (Supplementary Table S2). According to the generally accepted criterion for the definition of genomic species of Wayne et al. (1987) (i.e. based on DNA-DNA hybridization of $70 \%$ or greater with $\Delta T_{\mathrm{m}}$ less than $5^{\circ} \mathrm{C}$ ), the group of studied strains belong to P. brassicacearum (Achouak et al., 2000).

Detailed comparative taxonomic analysis revealed that, although the studied strains are similar to $P$. brassicacearum and $P$. thivervalensis in their ecology and some phenotypic properties, the new isolates maintain a different phenotype. Interestingly, although $P$. brassicacearum and $P$. thivervalensis are genetically and phylogenetically distinct, they appeared very similar phenotypically (Table 1; Achouak et al., 2000). In contrast, the group of studied strains maintain a clearly defined phenotype and can be distinguished easily from their phylogenetic relatives, including $P$. brassicacearum; for example, they produce characteristic pigments and antibiotics, are vigorous denitrifiers, do not have DNase and differ in the spectrum of organic compounds that they assimilate, particularly alcohols. $P$. corrugata and $P$. mediterranea do not produce fluorescent pigment or levan and $P$. kilonensis does not have arginine dihydrolase. Other differential characteristics of these bacteria are presented in Table 1. This analysis allows us to conclude that the group of studied strains merit the status of a subspecies. Hence, we propose to include the group of studied bacteria in P. brassicacearum and establish two novel subspecies within this species, Pseudomonas brassicacearum subsp. brassicacearum subsp. nov. and Pseudomonas brassicacearum subsp. neoaurantiaca subsp. nov.

\section{Emended description of Pseudomonas brassicacearum Achouak et al. 2000}

In addition to the characteristics reported in the original description by Achouak et al. (2000), the following properties are observed. Main non-polar fatty acids are $\mathrm{C}_{16: 0}, \mathrm{C}_{16: 1}(\mathrm{n}-7)$ and $\mathrm{C}_{18: 1}(\mathrm{n}-7)$, comprising up to $80 \%$ of the total fatty acids. Nitrate reduction, denitrification and DNase production are variable. Assimilation of D-mannitol, L-histidine and ethanol is variable. The DNA G+C content ranges from 60.8 to $62.9 \mathrm{~mol} \%$.

\section{Description of Pseudomonas brassicacearum subsp. brassicacearum subsp. nov.}

The description is identical to the original description of Pseudomonas brassicacearum reported by Achouak et al. (2000). The type strain is DBK $11^{\mathrm{T}}\left(=\mathrm{CFBP} 11706^{\mathrm{T}}=\mathrm{CIP}\right.$ $107059^{\mathrm{T}}=$ DSM $13227^{\mathrm{T}}=$ JCM $\left.11938^{\mathrm{T}}\right)$.

\section{Description of Pseudomonas brassicacearum subsp. neoaurantiaca subsp. nov.}

Pseudomonas brassicacearum subsp. neoaurantiaca (ne.o.au.ran'ti.a'ca. Gr. adj. neos new; N.L. fem. adj. 
aurantiaca orange-coloured and also a bacterial specific epithet; N.L. fem. adj. neoaurantiaca new aurantiaca, referring to the phenotypic similarity to Pseudomonas aurantiaca).

Rod-shaped cells, single, $1.0-1.5 \mu \mathrm{m}$ long and about $0.3-$ $0.8 \mu \mathrm{m}$ in diameter. Gram-negative. Motile, with three to five polar flagella. Aerobic. Chemorganotroph with respiratory metabolism. Produces a water-soluble yellow-green fluorescent pigment, a water- and alcohol-soluble redorange pigment and a complex of antimicrobial phloroglucinol derivates. The temperature range for growth is 4$37{ }^{\circ} \mathrm{C}$, with optimum growth at $25{ }^{\circ} \mathrm{C}$. No growth at $40{ }^{\circ} \mathrm{C}$. The $\mathrm{pH}$ for growth is $\mathrm{pH}$ 6.0-10.0, with optimum growth at $\mathrm{pH}$ 7.0. Does not accumulate poly- $\beta$-hydroxybutyrate as an intracellular reserve product. Positive for arginine dihydrolase; negative for lysine and ornithine decarboxylases. Forms levan from sucrose. Vigorous denitrifier. Does not oxidize gluconate to 2-ketogluconate. Liquefies gelatin and does not hydrolyse starch, agar, aesculin, chitin or DNA. Lipase production (hydrolysis of Tween 80) is variable. Only activities for alkaline phosphatase, esterase (C4), esterase lipase (C8), trypsin, acid phosphatase and naphthol-AS-BI-phosphohydrolase are detected in API ZYM tests. The following compounds are utilized as single sources of carbon and energy: D-glucose, D-xylose, Larabinose, D-mannose, D-galactose, D-fructose, sucrose, trehalose, gluconate, acetate, propionate, butyrate, valerate, caproate, heptanoate, caprylate, pelargonate, malate, lactate, succinate, fumarate, glutarate, citrate, isocitrate, $\alpha$ ketoglutarate, pyruvate, cis-aconitate, mannitol, sorbitol, inositol, glycerol, 2,3-butylene glycol, ethanol, n-propanol, n-butanol, isobutanol, benzoate, $p$-hydroxybenzoate, quinate, $\alpha$-alanine, $\beta$-alanine, L-serine, L-leucine, L-isoleucine, L-valine, L-lysine, L-arginine, L-aspartate, L-glutamate, Lornithine, $\gamma$-aminobutyrate, L-histidine, L-proline, L-tyrosine, L-phenylalanine, betaine and sarcosine. Strains isolated from oil-saturated soils utilize $\mathrm{C}_{6}-\mathrm{C}_{10}$ hydrocarbons and produce phloroglucinol derivates when grown in synthetic medium in a $\mathrm{C}_{6}-\mathrm{C}_{10}$ atmosphere with aeration (Smirnov \& Kiprianova, 1990). D-Fucose, L-rhamnose, maltose, cellobiose, lactose, starch, inulin, salicin, oxalate, maleate, adipate, pimelate, meso-tartrate, glycolate, itaconate, dulcitol, adonitol, mandelate, $o$-hydroxybenzoate, $m$ hydroxybenzoate, phthalate, phenol, phenylacetate, glycine, citrulline, L- and D-tryptophan, anthranilate, $p$-aminobenzoate, creatine, hippurate, pantothenate, acetamide and nicotinate are not utilized. The $\mathrm{G}+\mathrm{C}$ content of the DNA is $61.7-62.9 \mathrm{~mol} \%$.

The type strain is CIP $109457^{\mathrm{T}}$ (=ATCC $49054^{\mathrm{T}}=\mathrm{IMV}$ $387^{\mathrm{T}}=$ VKM B-1524 $4^{\mathrm{T}}$ ). Strains have been isolated from soils and the rhizosphere of plants in temperate areas.

\section{Acknowledgements}

This study was partly supported by the Australian Research Council (ARC) and in part by grants (State Contracts) from the Federal
Agency for Science and Innovations of the Ministry for Education and Science of the Russian Federation 'KMM' and 'Scientific Schools'.

\section{References}

Achouak, W., Sutra, L., Heulin, T., Meyer, J. M., Fromin, N., Degraeve, S., Christen, R. \& Gardan, L. (2000). Pseudomonas brassicacearum sp. nov. and Pseudomonas thivervalensis sp. nov., two root-associated bacteria isolated from Brassica napus and Arabidopsis thaliana. Int $J$ Syst Evol Microbiol 50, 9-18.

Ait Tayeb, L., Ageron, E., Grimont, F. \& Grimont, P. A. (2005). Molecular phylogeny of the genus Pseudomonas based on rpoB sequences and application for the identification of isolates. Res Microbiol 156, 763-773.

Anzai, Y., Kim, H., Park, J.-Y., Wakabayashi, H. \& Oyaizu, H. (2000). Phylogenetic affiliation of the pseudomonads based on 16S rRNA sequence. Int J Syst Evol Microbiol 50, 1563-1589.

Brosius, J., Palmer, M. L., Kennedy, P. J. \& Noller, H. F. (1978). Complete nucleotide sequence of a $16 \mathrm{~S}$ ribosomal RNA gene from Escherichia coli. Proc Natl Acad Sci U S A 75, 4801-4805.

Cashion, P., Holder-Franklin, M. A., McCully, J. \& Franklin, M. (1977). A rapid method for the base ratio determination of bacterial DNA. Anal Biochem 81, 461-466.

Catara, V., Sutra, L., Morineau, A., Achouak, W., Christen, R. \& Gardan, L. (2002). Phenotypic and genomic evidence for the revision of Pseudomonas corrugata and proposal of Pseudomonas mediterranea sp. nov. Int J Syst Evol Microbiol 52, 1749-1758.

Chevenet, F., Brun, C., Bañuls, A. L., Jacq, B. \& Christen, R. (2006). TreeDyn: towards dynamic graphics and annotations for analyses of trees. BMC Bioinformatics 7, 439.

Chun, J., Lee, J.-H., Jung, Y., Kim, M., Kim, S., Kim, B. K. \& Lim, Y. W. (2007). EzTaxon: a web-based tool for the identification of prokaryotes based on $16 \mathrm{~S}$ ribosomal RNA gene sequences. Int J Syst Evol Microbiol 57, 2259-2261.

De Ley, J., Cattoir, H. \& Reynaerts, A. (1970). The quantitative measurement of DNA hybridization from renaturation rates. Eur $J$ Biochem 12, 133-142.

Galtier, N., Gouy, M. \& Gautier, C. (1996). SeaView and PHYLO_WIN, two graphic tools for sequence alignment and molecular phylogeny. Comput Appl Biosci 12, 543-548.

Gascuel, O. (1997). BIONJ: an improved version of the NJ algorithm based on a simple model of sequence data. Mol Biol Evol 14, 685-695.

Guindon, S. \& Gascuel, O. (2003). A simple, fast and accurate algorithm to estimate large phylogenies by maximum likelihood. Syst Biol 52, 696-704.

Hugh, R. \& Leifson, E. (1953). The taxonomic significance of fermentative versus oxidative metabolism of carbohydrates by various gram negative bacteria. J Bacteriol 66, 24-26.

King, E. O., Ward, M. K. \& Raney, D. E. (1954). Two simple media for the demonstration of pyocyanin and fluorescein. J Lab Clin Med 44, 301-307.

Kiprianova, E. A., Levanova, G. F., Novova, E. V., Smirnov, V. V. \& Garagulia, A. D. (1985). Taxonomic study of Pseudomonas aurantiaca Nakhimovskaya, 1948 and the proposal of a neotype strain of this species. Mikrobiologiia 54, 434-440 (in Russian).

Larkin, M. A., Blackshields, G., Brown, N. P., Chenna, R., McGettigan, P. A., McWilliam, H., Valentin, F., Wallace, I. M., Wilm, A. \& other authors (2007). CLUSTAL $W$ and CLUSTAL_X version 2.0. Bioinformatics 23, 2947-2948.

Marmur, J. (1961). A procedure for the isolation of deoxyribonucleic acid from microorganisms. J Mol Biol 3, 208-218. 
Marmur, J. \& Doty, P. (1962). Determination of the base composition of deoxyribonucleic acid from its thermal denaturation temperature. J Mol Biol 5, 109-118.

Moore, E. R. B., Mau, M., Arnscherdt, A., Bottger, E. C., Hutson, R. A., Collins, M. D., Van De Peer, Y., De Wachter, R. \& Timmis, K. N. (1996). The determination and comparison of the 16S rRNA gene sequence of species of the genus Pseudomonas (sensu stricto) and estimation of the natural intrageneric relationships. Syst Appl Microbiol 19, 478-492.

Palleroni, N. J. (1984). Genus I. Pseudomonas Migula 1894, $237^{\mathrm{AL}}$. In Bergey's Manual of Systematic Bacteriology, vol. 1, pp. 141-199. Edited by N. R. Krieg \& J. G. Holt. Baltimore: Williams \& Wilkins.

Palleroni, N. J. (2005). Genus I. Pseudomonas Migula 1894, 237 ${ }^{\mathrm{AL}}$. In Bergey's Manual of Systematic Bacteriology, 2nd edn, vol. 2, part B, pp. 323-379. Edited by D. J. Brenner, N. R. Krieg, J. T. Staley \& G. M. Garrity. New York: Springer.

Peix, A., Valverde, A., Rivas, R., Igual, J. M., Ramírez-Bahena, M.-H., Mateos, P. F., Santa-Regina, I., Rodríguez-Barrueco, C., MartínezMolina, E. \& Velázquez, E. (2007). Reclassification of Pseudomonas aurantiaca as a synonym of Pseudomonas chlororaphis and proposal of three subspecies, P. chlororaphis subsp. chlororaphis subsp. nov., $P$. chlororaphis subsp. aureofaciens subsp. nov., comb. nov. and $P$. chlororaphis subsp. aurantiaca subsp. nov., comb. nov. Int J Syst Evol Microbiol 57, 1286-1290.

Sikorski, J., Stackebrandt, E. \& Wackernagel, W. (2001). Pseudomonas kilonensis sp. nov., a bacterium isolated from agricultural soil. Int J Syst Evol Microbiol 51, 1549-1555.

Smirnov, V. V. \& Kiprianova, E. A. (1990). Bacteria of the Genus Pseudomonas. Kiev: Naukova Dumka (in Russian).

Stanier, R. Y., Palleroni, N. J. \& Doudoroff, M. (1966). The aerobic pseudomonads: a taxonomic study. J Gen Microbiol 43, 159-271.

Svetashev, V. I., Vysotskii, M. V., Ivanova, E. P. \& Mikhailov, V. V. (1995). Cellular fatty acid of Alteromonas species. Syst Appl Microbiol 18, 37-43.

Wayne, L. G., Brenner, D. J., Colwell, R. R., Grimont, P. A. D., Kandler, O., Krichevsky, M. I., Moore, L. H., Moore, W. E. C., Murray, R. G. E. \& other authors (1987). International Committee on Systematic Bacteriology. Report of the ad hoc committee on reconciliation of approaches to bacterial systematics. Int J Syst Bacteriol 37, 463-464.

Yamamoto, S., Kasai, H., Arnold, D. L., Jackson, R. W., Vivian, A. \& Harayama, S. (2000). Phylogeny of the genus Pseudomonas: intrageneric structure reconstructed from the nucleotide sequences of gyrB and rpoD genes. Microbiology 146, 2385-2394. 